\title{
Energy expenditure and body composition in children with Crohn's disease: effect of enteral nutrition and treatment with prednisolone
}

\author{
M Azcue, M Rashid, A Griffiths, P B Pencharz
}

\begin{abstract}
Background-Malnutrition and growth retardation are common complications of Crohn's disease in children. The contribution of resting energy expenditure (REE) to malnutrition is unclear.

Aims-To characterise the REE and body composition in children with Crohn's disease and compare them with normal controls and patients with anorexia nervosa; to compare the effects of prednisolone and enteral nutrition on energy expenditure and body composition.
\end{abstract}

Subjects-Twenty four children with Crohn's disease, 19 malnourished females with anorexia nervosa, and 22 healthy control subjects were studied.

Methods-In children with Crohn's disease measurements were done when the disease was acute and repeated at one and three months after treatment with either prednisolone or enteral nutrition. Resting energy expenditure was measured by indirect calorimetry and body composition by anthropometry, bioelectrical impedance analysis, total body potassium, $\mathrm{H}_{2}{ }^{18} \mathrm{O}$, and bromide space studies.

Results-Body weight and ideal body weight were significantly lower in patients with Crohn's disease than in healthy controls. Lean tissue was depleted and there was an increase in extracellular water. Per unit of lean body mass, there was no difference between REE in patients with Crohn's disease and controls, whereas patients with anorexia nervosa had significantly reduced REE. With enteral nutrition all body compartments and REE increased significantly $(p<0.001)$. In a subgroup of age-matched men there was a significant increase in height after three months of enteral nutrition compared with prednisolone $(p<0.01)$. Those treated with steroids did not show a significant change in height but did show an increase in all body compartments. However, intracellular water as well as lean body mass accretion were significantly higher in the enteral nutrition group than in the prednisolone group.

Conclusions-Despite being malnourished, children with Crohn's disease fail to adapt their REE per unit of lean body mass. This might be a factor contributing to their malnutrition. Lean tissue accretion is higher in patients treated with enteral nutrition than in those treated with prednisolone.

(Gut 1997; 41: 203-208)

Keywords: Crohn's disease; resting energy expenditure; body composition; anorexia nervosa; prednisolone; enteral nutrition

Childhood Crohn's disease is frequently complicated by growth impairment and pubertal delay. The aetiology is multifactorial. Chronic daily use of corticosteroids will adversely affect linear growth but untreated inflammatory bowel disease itself is also detrimental to growth. Most studies suggest that chronic caloric insufficiency related primarily to inadequate intake is the single most important factor in growth failure seen in children with Crohn's disease. ${ }^{1-5}$ Treatment with enteral nutrition constitutes primary therapy of active inflammation and can lead to improved growth as adequate calories are provided. ${ }^{35-7}$ This therapy is desirable in a child in whom growth failure can be a manifestation of the underlying disease. Although an increase in energy expenditure might be anticipated in chronic inflammatory disease, resting energy expenditure (REE) in Crohn's disease has been shown not to be significantly increased over the predicted normal values. ${ }^{8}$ However, an increase in REE has been described in a subgroup of malnourished patients. ${ }^{8}{ }^{9}$ Total daily energy expenditure in Crohn's disease has not been found to be increased. ${ }^{10}$ Neither the effects of prednisolone nor enteral nutrition on energy expenditure and body composition in children and adolescents with Crohn's disease have been described. The objectives of this study were to characterise the body composition and REE in relation to the degree of malnutrition in paediatric patients with Crohn's disease compared with normal controls and adolescents with anorexia nervosa and to compare the effects of prednisolone and enteral nutrition on energy expenditure and body composition in patients with Crohn's disease.

\section{Methods}

SUBJECTS

Twenty four patients with Crohn's disease were recruited from the Inflammatory Bowel Disease Clinic at The Hospital for Sick Children, Toronto. They all had at least moderately active disease with a Crohn's disease activity index (CDAI) of $>150$. All patients had ileocolonic disease. Four patients were on low dose
Accepted for publication 24 December 1997 
TABLE 1 Comparison of patients with Crohn's disease (before treatment), controls and patients with anorexia nervosa

\begin{tabular}{|c|c|c|c|c|c|c|}
\hline \multirow[b]{2}{*}{ Age (y) } & \multicolumn{2}{|c|}{ Crohn's disease $(n=24)$} & \multicolumn{2}{|c|}{ Controls $(n=22)$} & \multicolumn{2}{|c|}{$\begin{array}{l}\text { Anorexia nervosa } \\
(n=19)\end{array}$} \\
\hline & 13.1 & $(2.2)^{\mathrm{a}}$ & 13.7 & $(4.2)^{\mathrm{a}}$ & 15.6 & $(1.4)^{\mathrm{b}}$ \\
\hline Sex & $18 \mathrm{M} / 6 \mathrm{l}$ & & $15 \mathrm{M} / 7 \mathrm{l}$ & & $19 \mathrm{~F}$ & \\
\hline Height $(\mathrm{cm})$ & 151.2 & $(14.9)^{\mathrm{a}}$ & 154.7 & $(16)^{a, b}$ & 162.9 & $(7.0)^{\mathrm{b}}$ \\
\hline Weight (kg) & 36.5 & $(10.0)^{\mathrm{a}}$ & 47.6 & $(17.3)^{\mathrm{b}}$ & 41.6 & $(5.9)^{\mathrm{a}, \mathrm{b}}$ \\
\hline IBW $(\%)$ & 87.1 & $(11.1)^{\mathrm{a}}$ & 100.1 & $(9.1)^{\mathrm{b}}$ & 73.5 & $(4.4)^{c}$ \\
\hline TBW (L), $\mathrm{H}_{2}{ }^{18} \mathrm{O}$ & 22.5 & $(6.0)^{\mathrm{a}}$ & 32.4 & $(8.8)^{\mathrm{b}}$ & 26.2 & $(3.4)^{\mathrm{a}}$ \\
\hline TBW (L), BIA & 23.1 & $(6.5)^{\mathrm{a}}$ & 29.1 & $(8.3)^{\mathrm{b}}$ & 26.9 & $(2.7)^{\mathrm{a}, \mathrm{b}}$ \\
\hline $\mathrm{ECW}(\mathrm{L})$ & 10.1 & $(2.7)^{\mathrm{a}}$ & 12.5 & $(2.9)^{\mathrm{b}}$ & 12.0 & $(1.7)^{\mathrm{b}}$ \\
\hline $\mathrm{ECW}$ (L), BIA & 10.2 & $(2.5)^{\mathrm{a}}$ & 12.2 & $(2.9)^{\mathrm{b}}$ & 11.8 & $(1.2)^{\mathrm{b}}$ \\
\hline ICW (L) & 12.2 & $(4.5)^{\mathrm{a}}$ & 19.9 & $(6.8)^{b}$ & 14.5 & $(3.2)^{\mathrm{b}}$ \\
\hline ICW (L), BIA & 12.9 & $(4.1)^{\mathrm{a}}$ & 17.0 & $(5.4)^{\mathrm{b}}$ & 15.1 & $(1.6)^{a, b}$ \\
\hline ECW/ICW & 0.91 & $(0.35)^{\mathrm{a}}$ & 0.67 & $(0.18)^{\mathrm{b}}$ & 0.87 & $(0.27)^{\mathrm{a}, \mathrm{b}}$ \\
\hline $\mathrm{ECW} / \mathrm{ICW}, \mathrm{BIA}$ & 0.8 & $(0.09)^{\mathrm{a}}$ & 0.73 & $(0.06)^{\mathrm{b}}$ & 0.77 & $(0.05)^{\mathrm{a}}$ \\
\hline $\mathrm{LBM}(\mathrm{kg}), \mathrm{H}_{2}{ }^{18} \mathrm{O}$ & 30.8 & $(8.2)^{\mathrm{a}}$ & 44.3 & $(12.0)^{\mathrm{b}}$ & 35.8 & $(4.6)^{\mathrm{c}}$ \\
\hline LBM $(\mathrm{kg})$, BIA & 31.6 & $(8.9)^{a}$ & 38.3 & $(11.4)^{\mathrm{b}}$ & 36.8 & $(3.7)^{\mathrm{a}, \mathrm{b}}$ \\
\hline LBM (kg), TBK & 27.0 & $(8.1)^{\mathrm{a}}$ & 34.7 & $(11.2)^{\mathrm{b}}$ & - & \\
\hline FFM $(\mathrm{kg})$ & 30.4 & $(8.6)^{a, b}$ & 28.4 & $(8.3)^{\mathrm{a}}$ & 33.3 & $(3.7)^{\mathrm{b}}$ \\
\hline $\mathrm{LBM}(\% \mathrm{wt}), \mathrm{H}_{2}{ }^{18} \mathrm{O}$ & 85.6 & $(8.1)^{\mathrm{a}}$ & 84.6 & $(17.8)^{\mathrm{a}}$ & 86.9 & $(12.7)^{\mathrm{a}}$ \\
\hline LBM (\%wt), BIA & 86.7 & $(5.5)^{\mathrm{a}}$ & 86.5 & $(12.9)^{\mathrm{a}}$ & 89.5 & $(12.3)^{\mathrm{a}}$ \\
\hline FFM (\%wt) & 87.2 & $(4.3)^{\mathrm{a}}$ & 64.9 & $(12.9)^{\mathrm{b}}$ & 80.4 & $(3.3)^{\mathrm{a}}$ \\
\hline ECW (\%wt) & 28.7 & $(3.9)^{\mathrm{a}}$ & 24.0 & $(3.7)^{\mathrm{b}}$ & 29.1 & $(5.9)^{\mathrm{a}}$ \\
\hline ECW (\%wt), BIA & 28.1 & $(2.6)^{a}$ & 26.8 & $(4.6)^{a}$ & 28.8 & $(4.8)^{\mathrm{a}}$ \\
\hline Fat (\%wt) & 16.8 & $(4.3)^{\mathrm{a}}$ & 35.1 & $(12.9)^{\mathrm{b}}$ & 19.5 & $(3.3)^{\mathrm{a}}$ \\
\hline $\mathrm{REE}$ (kcal/day) & 1250 & $(318)^{a}$ & 1471 & $(317)^{b}$ & 1021 & $(117)^{\mathrm{c}}$ \\
\hline REE (\% predicted) & 97.5 & $(14)^{\mathrm{a}}$ & 104.9 & $(13.3)^{\mathrm{a}}$ & 77.8 & $(11.8)^{\mathrm{b}}$ \\
\hline $\mathrm{REE} / \mathrm{LBM}$ & 40.3 & $(5.9)^{\mathrm{a}}$ & 39.1 & $(6.3)^{\mathrm{a}}$ & 28.2 & $(5.2)^{\mathrm{b}}$ \\
\hline
\end{tabular}

Values are expressed as mean (SD).

For each parameter, means with different superscripts are significantly different $(p<0.05)$.

IBW, ideal body weight; REE, resting energy expenditure; LBM, lean body mass; BIA, bioelectrical impedance analysis; TBK, total body potassium; SKF, skin fold; FFM, fat free mass; TBW, total body water; ICW, intracellular water; ECW, extracellular water.

TABLE 2 Mean (SD) laboratory data of patients with Crohn's disease before treatment

\begin{tabular}{lc}
\hline $\begin{array}{l}\text { Haemoglobin } \\
(\mathrm{g} / \mathrm{l})\end{array}$ & $114(12.7)$ \\
ESR $(\mathrm{mm} / \mathrm{h})$ & $30(18)$ \\
$\begin{array}{l}\text { Serum albumin } \\
(\mathrm{g} / \mathrm{l})\end{array}$ & $34(2.1)$ \\
\hline
\end{tabular}

ESR, erythrocyte sedimentation rate.
( $<10 \mathrm{mg}$ ) alternate day therapy with prednisolone. None of the patients had fever, abscess, or draining fistula. Six patients were randomised to their treatment group as part of a multicentre study comparing exclusive semielemental enteral nutrition with prednisolone in the treatment of active Crohn's disease. ${ }^{11}$ The remainder of the patients chose their treatment because of family preferences or past individual treatment success. Two patients were treated with enteral nutrition in order to be weaned from prednisolone. Two patients in the enteral nutrition group and three in the prednisolone group were newly diagnosed.

TREATMENT REGIMENS

The prednisolone treatment group received $1 \mathrm{mg} / \mathrm{kg} /$ day for one month and then a gradual daily reduction by $5 \mathrm{mg}$ per week over the next two months. Patients in the enteral nutrition treatment group were hospitalised for a few days to learn the technique of nasogastric tube insertion and formula infusion. Once home, each infused $1500-2400 \mathrm{ml}$ of commercial elemental formula (Vital, Ross Laboratories, Montreal, Quebec) each night for a period of five to six weeks. This provided approximately $60 \mathrm{kcal} / \mathrm{kg} /$ day (individual variations occurred depending on tolerance, satiety, hunger). Only clear fluids were allowed orally for this period. After four weeks the patients were allowed to decrease the frequency of feedings by approximately one night a week. After two months most patients had discontinued liquid diet feeding. There were no complications from nasogastric tube feedings.

The control group comprised 22 normal subjects ( 15 males) matched for age. A group of 19 malnourished adolescent females with anorexia nervosa was also studied. These patients were recruited from the Adolescent
Medicine Clinic at the Hospital for Sick Children, Toronto. All patients with anorexia nervosa had a body weight $<85 \%$ of predicted weight for height. The nutritional status and body composition of each subject was determined by anthropometry, $\mathrm{H}_{2}{ }^{18} \mathrm{O}$ isotope and bromide spaces, total body potassium, and bioelectrical impedance analysis.

Informed consent was obtained from the patients and the controls. The study was approved by the Human Subjects Review Committee of The Hospital for Sick Children.

\section{ANTHROPOMETRY}

The ideal body weight (IBW) was calculated ${ }^{12}$ by plotting the height and weight values on the growth and development charts of Tanner and Whitehouse. ${ }^{13}$ Skinfolds were measured using Harpenden calipers (John Bulls, British Indicators Ltd, UK). The biceps, triceps, subscapular, and suprailiac skinfolds were measured using standard techniques. Using the sum of these four skinfolds, total body fat and hence fat free mass was calculated. ${ }^{14}$

\section{BIOELECTRICAL IMPEDANCE ANALYSIS}

Body impedance was measured with a four terminal impedance analyser (BIA 101 Impedance Analyser, RJL Systems Inc, Detroit, Michigan, USA). The system introduces a low current of $800 \mathrm{~mA}$ at $50 \mathrm{kHz}$. The measurements were made while the subjects lay comfortably on the bed with the limbs abducted from the body. The injector and detector electrodes were positioned according to the manufacturer's instructions. The voltage drop detected by the proximal electrodes was displayed as resistance $(\mathrm{R})$ and reactance $(\mathrm{Xc})$ The lowest reading of three stable measurements was used. Resistance values obtained were used to calculate total body water (TBW) and extracellular water (ECW) ${ }^{15}$ Intracellular water (ICW) was calculated as the difference between TBW and ECW.

\section{TOTAL BODY POTASSIUM MEASUREMENTS}

Naturally occurring ${ }^{40} \mathrm{~K}$ measurements were performed in a whole body scintillation counter ${ }^{16}$ in patients with Crohn's disease and controls but not in the anorexia nervosa group. Total body potassium measurements were obtained by counting the pulses in the photopeak during a 10 minute period. The ${ }^{40} \mathrm{~K}$ counts were standardised for variation in gamma efficiency with differences in body size using ${ }^{42} \mathrm{~K}$ internal standardisation.

\section{TBW MEASUREMENT WITH $\mathrm{H}_{2}{ }^{18} \mathrm{O}$ AND ECW WITH} BROMIDE SPACE STUDY

Total body water was measured from plasma samples using the $\mathrm{H}_{2}{ }^{18} \mathrm{O}$ dilution technique ${ }^{17}$ and extracellular water was measured as the corrected bromide space. ${ }^{18}$ Subjects were studied after an overnight fast. Both labels were given orally. An initial blood sample was taken followed by oral administration of the labels. After a period of equilibration of three hours a second sample was taken. ${ }^{18}$ The bromide concentration was measured by in vitro neutron 
TABLE 3 Comparison of patients with Crohn's disease (before treatment) with ideal body weight $(I B W)<85 \%$ and patients with anorexia nervosa with $I B W<85 \%$

\begin{tabular}{lccl}
\hline & $\begin{array}{c}\text { Crohn's disease } \\
(n=12,8 M / 4 F)\end{array}$ & $\begin{array}{c}\text { Anorexia nervosa } \\
(n=19,0 M / 19 F)\end{array}$ & $p$ Value \\
\hline Age (y) & $13.8(1.7)$ & $15.6(4.2)$ & 0.0057 \\
Height (cm) & $157.7(7.7)$ & $162.9(7.0)$ & 0.628 \\
Weight (kg) & $37.5(5.9)$ & $41.6(5.9)$ & 0.07 \\
REE (kcal/day) & $1254(210)$ & $1021(117)$ & 0.003 \\
REE (\%predicted) & $97.8(11.4)$ & $77.8(11.8)$ & 0.0001 \\
REE/LBM & $38.5(4.3)$ & $28.2(5.2)$ & 0.00001 \\
\hline
\end{tabular}

Values are expressed as mean (SD).

IBW, ideal body weight; REE, resting energy expenditure; LBM, lean body mass.

$\mathrm{LBM}$ was determined from $\mathrm{H}_{2}{ }^{18} \mathrm{O}$ dilution.

activation and ${ }^{18} \mathrm{O}$ enrichment by isotope ratio mass spectrometry (Micromass 602D, Vacuum Generators, UK).

RESTING ENERGY EXPENDITURE

Resting energy expenditure (REE) studies were carried out by open circuit indirect calorimetry (2900 Energy Measurement Module, SensorMedics, Anaheim, California, USA) as previously described. ${ }^{19}$ Briefly, subjects were studied following a minimum 12 hour fast and were required to rest on a bed. A clear plastic hood was placed over the head and air was drawn at a constant rate through the hood. In some patients a ventilated face mask was used instead of the hood. Ventilation of the hood or mask was measured by a mass flow meter. Oxygen difference was measured by a paramagnetic analyser and carbon dioxide by an infrared analyser. The percentage of predicted REE was calculated by dividing the measured REE by the values developed by the World Health Organisation for predicted REE based on age, height, weight, and sex..$^{20}$ All of the above measurements were performed in patients with Crohn's disease before starting treatment and were repeated one month after the start of treatment (prednisolone or enteral nutrition) and again two months later. The controls and the group with anorexia nervosa had only one measurement. None of the subjects was pyrexial at the time REE was measured.

STATISTICAL ANALYSIS

All results are expressed as mean (SD). One way ANOVA and analysis of covariance were used to compare patients with Crohn's disease (before treatment) with controls and anorexia nervosa patients. Malnourished patients with Crohn's disease (IBW <85\%) and anorexia nervosa were compared by the Student's $t$ test. Repeated measures analysis of variance with univariate ANOVA was used to assess statistical significance between time (within subject) and between treatments (between subject) in the Crohn's disease group. A p value of $<0.05$ was used for all statistical significance.

\section{Results}

The baseline characteristics of the patients with Crohn's disease, anorexia nervosa, and controls are shown in table 1 . The laboratory data of patients with Crohn's disease are shown in table 2. The duration of disease was 2.9 (2.0) years and the most common complaints in these patients were abdominal pain, weight

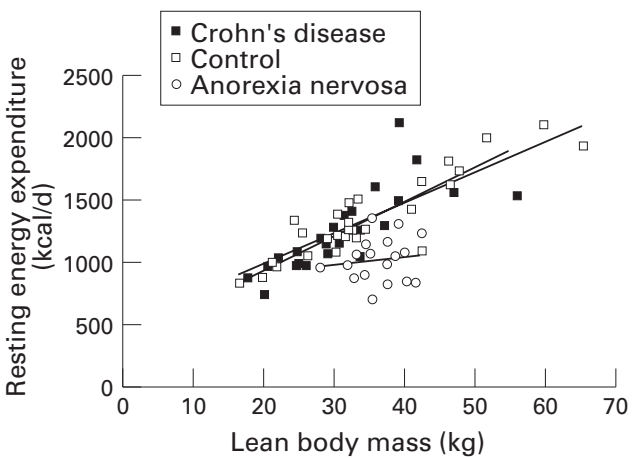

Figure 1: Relation between resting energy expenditure and lean body mass by bioelectric impedance analysis in children with active Crohn's disease, (regression line $n=24$, $r=0.77, S E E=206, p<0.001$ ), healthy controls (regression line $n=22, r=0.90, S E E=149, p<0.001$ ), and patients with anorexia nervosa (regression line $n=19, r=0.14, S E E=181$, $p<0.12)$.

loss, and poor energy level. Height was not significantly different from normal subjects matched for age. However, both body weight and ideal body weight were significantly lower than in normal subjects $(\mathrm{p}<0.01$ and $\mathrm{p}<0.003$, respectively). All patients with anorexia nervosa had a body weight $<85 \%$ of predicted weight for height $(73.5(4.4) \%$ IBW). As a group they were taller than the patients with Crohn's disease.

Lean body mass was significantly depleted in absolute terms in patients with Crohn's disease compared with controls, but not as a percentage of body weight. Extracellular space was decreased in absolute numbers but as a percentage of body weight there was expansion of ECW in patients with Crohn's disease compared with controls. The ratio of ECW to ICW was also significantly increased in patients with Crohn's disease compared with controls.

The REE of patients with Crohn's disease was not different from the controls whether expressed as calories per kg of body weight or per kg of lean body mass. Patients with anorexia nervosa showed a significant reduction in REE compared with patients with Crohn's disease and controls. Figure 1 shows the individual data for the three groups; analysis of covariance of REE versus lean body mass in the three groups shows that there was no difference in the slope of patients with Crohn's disease and controls, but the slope of the curve for patients with anorexia nervosa was significantly different.

Due to the heterogeneous nature of the total group of patients with Crohn's disease, a subgroup with ideal body weight for height $<85 \%$ was compared with the anorexia nervosa group. REE was significantly higher in these malnourished Crohn's patients compared with comparably malnourished females with anorexia nervosa (table 3 ).

Table 4 shows the characteristics of the subgroups of patients with Crohn's disease assigned to either enteral nutrition or prednisolone before treatment and after one and three months of therapy. The overall activity of the disease and clinical picture were similar in the two groups. Although not statistically significant, the patients in the prednisolone 
TABLE 4 Comparison of patients with Crohn's disease treated with enteral nutrition $(n=12,7 M / 5 F)$ or prednisolone $(n=12,10 M / 2 F)$

\begin{tabular}{|c|c|c|c|c|c|}
\hline \multirow[b]{2}{*}{ Age (y) } & \multirow{2}{*}{$\begin{array}{l}\text { Treatment } \\
\text { Enteral nutrition }\end{array}$} & O Months & One month & \multicolumn{2}{|c|}{ Three months } \\
\hline & & $12.8 \quad(15.9)$ & - & - & \\
\hline & Prednisolone & $13.95(1.8)$ & - & - & \\
\hline \multirow[t]{2}{*}{ Height $(\mathrm{cm})$} & Enteral nutrition & $147.2 \quad(15.9)$ & $147.0 \quad(17.3)$ & 147.1 & $(16.7)$ \\
\hline & Prednisolone & $156.7(9.9)$ & $157.0 \quad(9.5)$ & 156.6 & $(10.7)$ \\
\hline \multirow[t]{2}{*}{ Weight (kg) } & Enteral nutrition & $32.6(8.8)^{a}$ & $38.2(11.7)^{\mathrm{b}}$ & 40.9 & $(12.1)^{\mathrm{c}}$ \\
\hline & Prednisolone & $41.0 \quad(9.0)^{\mathrm{a}}$ & $47.3(9.0)^{\mathrm{b}}$ & 51.4 & $(10.3)^{\mathrm{c}}$ \\
\hline \multirow[t]{2}{*}{ IBW (\%) } & Enteral nutrition & $83.9(11.3)^{\mathrm{a}}$ & $97.9(15.8)^{\mathrm{b}}$ & 106 & $(13.8)^{c}$ \\
\hline & Prednisolone & $89.1 \quad(9.8)^{\mathrm{a}}$ & $103.9(15.6)^{\mathrm{b}}$ & 114.2 & $(17.9)^{\mathrm{c}}$ \\
\hline \multirow[t]{2}{*}{ REE (kcal/day) } & Enteral nutrition & $(283)^{\mathrm{a}}$ & $(535)^{b}$ & 1453 & $(307)^{\mathrm{c}}$ \\
\hline & Prednisolone & $(308)^{a}$ & $(265)^{a}$ & 1592 & $(362)^{\mathrm{b}}$ \\
\hline \multirow{2}{*}{ REE (\% predicted) } & Enteral nutrition & $96.6(13.1)^{\mathrm{a}}$ & $108.7(21)^{\mathrm{A}, \mathrm{b}}$ & 110 & $(114.4)^{\mathrm{B}, \mathrm{b}}$ \\
\hline & Prednisolone & $100.8 \quad(15.9)$ & $97.4(13.6)^{\mathrm{C}}$ & 102.9 & $(16.2)^{\mathrm{D}}$ \\
\hline \multirow[t]{2}{*}{ LBM } & Enteral nutrition & $27.56(10.1)^{\mathrm{a}}$ & $32.5(11.6)^{\mathrm{b}}$ & 34.7 & $(10.6)^{c}$ \\
\hline & Prednisolone & $34.5(8.2)^{\mathrm{a}}$ & $39.06(10.7)^{\mathrm{b}}$ & 38.9 & $(10.8)^{\mathrm{b}}$ \\
\hline \multirow[t]{2}{*}{ LBM (\%wt) } & Enteral nutrition & $86.6(8.9)$ & $88.8 \quad(9.9)$ & 83.2 & $(5.7)$ \\
\hline & Prednisolone & $87.5 \quad(9.4)$ & $79.1 \quad(9.4)$ & 77.7 & (11.4) \\
\hline \multirow[t]{2}{*}{ Fat (\%wt) } & Enteral nutrition & $16.19(4.7)^{\mathrm{a}}$ & $20.8(5.2)^{\mathrm{b}}$ & 22.0 & $(5.7)^{c}$ \\
\hline & Prednisolone & $17.4 \quad(4.0)^{\mathrm{a}}$ & $20.5(5.5)^{\mathrm{b}}$ & 24.1 & $(5.9)^{\mathrm{c}}$ \\
\hline \multirow{2}{*}{ TBW (L) } & Enteral nutrition & $20.12(4.8)^{\mathrm{a}}$ & $23.7(8.4)^{\mathrm{A}, \mathrm{b}}$ & 25.4 & $(7.8)^{\mathrm{B}, \mathrm{c}}$ \\
\hline & Prednisolone & $25.2(6.0)^{\mathrm{a}}$ & $25.8(7.8)^{\mathrm{C}, \mathrm{b}}$ & 28.4 & $(7.9)^{\mathrm{D}, \mathrm{b}}$ \\
\hline \multirow[t]{2}{*}{$\mathrm{ECW}(\mathrm{L})$} & Enteral nutrition & $9.24(2.7)^{\mathrm{a}}$ & $9.2(4.7)^{\mathrm{A}, \mathrm{b}}$ & 10.7 & $(5.5)^{\mathrm{B}, \mathrm{c}}$ \\
\hline & Prednisolone & $11.07(2.3)^{\mathrm{a}}$ & $12.8(2.3)^{\mathrm{C}, \mathrm{b}}$ & 11.56 & $(2.7)^{\mathrm{D}, \mathrm{c}}$ \\
\hline \multirow[t]{2}{*}{ ICW (L) } & Enteral nutrition & $10.6(3.1)^{\mathrm{a}}$ & $13.5(4.9)^{\mathrm{b}}$ & 13.9 & $(4.7)^{\mathrm{A}, \mathrm{b}}$ \\
\hline & Prednisolone & $14.1(4.9)^{\mathrm{a}}$ & $17.8(4.56)^{\mathrm{b}}$ & 16.9 & $(5.6)^{\mathrm{B}, \mathrm{b}}$ \\
\hline \multirow[t]{2}{*}{ ECW (\%wt) } & Enteral nutrition & $29.0(3.5)^{\mathrm{a}}$ & $25.2(8.9)^{\mathrm{b}}$ & 25.4 & $(10.3)^{b}$ \\
\hline & Prednisolone & $28.4(4.7)^{\mathrm{a}}$ & $25.0(2.7)^{\mathrm{b}}$ & 23.1 & $(2.5)^{c}$ \\
\hline \multirow[t]{2}{*}{ ECW/ICW } & Enteral nutrition & $0.94(0.27)^{\mathrm{a}}$ & $0.77(0.09)^{\mathrm{b}}$ & 0.73 & $(0.33)^{\mathrm{b}}$ \\
\hline & Prednisolone & $0.88(0.45)$ & $0.73(0.12)$ & 0.72 & $(0.16)$ \\
\hline
\end{tabular}

Values are expressed as mean (SD).

0 Months, before treatment; one month, one month after treatment; three months, three months after treatment.

There was no statistically significant difference between the two groups before treatment.

IBW, ideal body weight; REE, resting energy expenditure; LBM, lean body mass; TBW, total body water; ICW, intracellular water; ECW, extracellular water.

Lower case superscript letters denote comparisons within subject across the 0 , one and three month time points in each of the two treatment groups. Means with different superscripts are significantly different $(p<0.05)$.

Differences in the response to treatment between treatment groups (enterally fed compared with prednisolone treated) are shown using superscript capital letters. Responses to treatment were tested as the changes from before treatment $(0$ months $)$ to either one month or three months. Means with different superscripts are significantly different $(\mathrm{p}<0.05)$.

group were numerically older, taller, and heavier. Body composition and REE were similar in the two groups at the start of treatment.

In the enteral nutrition group ideal body weight was $106 \%$ at the end of the treatment. All body compartments were significantly increased over the treatment period. Both ECW as percentage of body weight and the ratio of ECW to ICW decreased with treatment. Resting energy expenditure increased significantly in this group, whether in absolute numbers or as a percentage of predicted for weight and age. Analysis of covariance showed that there was no significant change in the regression line between REE and lean body mass over the three month treatment period.

There was no significant increase in height of patients treated with prednisolone over the three month period. Ideal body weight at one and three months was significantly increased. There was also an increase in all body compartments - namely, lean body mass, extracellular water, and fat. The ratio of extracellular to intracellular water in the prednisolone group did not change. Resting energy expenditure was increased in absolute numbers at three months compared with the value before treatment but did not increase as a percentage of predicted for body weight and age. The ratio of REE to lean body mass was not different from controls or the pretreatment stage.

At one and three months both treatments were equally able to increase total body weight (average gain of $9.5 \mathrm{~kg}$ ). The gain in body fat was not significantly different between groups although, as a percentage of body weight, the patients in the prednisolone group showed a trend towards a higher percentage of fat at the end of the treatment $(p=0.07)$. Changes in total body water and intracellular water were significantly larger in the enteral nutrition group than in the prednisolone group. Changes in extracellular space were significantly lower in the prednisolone group than in the enteral nutrition group. The ratio of potassium to intracellular water was significantly increased $(p<0.05)$ in the prednisolone group after one month of treatment (data not shown), but not after three months of treatment.

The effects of both treatments on REE are also shown in table 4 . At one month and three months of treatment there was a significant difference between the change in REE of the enteral nutrition group and the prednisolone group with a mean increase in REE at three months of $330 \mathrm{kcal} /$ day in the enteral nutrition group and $212 \mathrm{kcal} /$ day in the prednisolone group. For the same ideal body weight and percentage body fat at one month of treatment the change in REE with prednisolone was not significant from baseline but in the enteral nutrition group it was highly significant $(p<0.001)$. Analysis of covariance at three months showed an effect of treatment (enteral nutrition versus prednisolone) on the slope of the regression of REE versus lean tissue (by $\mathrm{H}_{2}{ }^{18} \mathrm{O}$, total body potassium, bioelectrical impedance analysis, and skinfolds) as opposed to body weight. This could be explained by a change in the proportion of lean versus fat 
mass in the prednisolone group at three months of treatment.

Due to the initial differences in sex, age, and Tanner staging between the two treatment groups, subgroups of 10 males matched for age and Tanner stage were compared. The enteral nutrition group showed a significant increase in height compared with the prednisolone group at three months. Mean average height gain was $1.8 \mathrm{~cm}$ with enteral nutrition and $0.5 \mathrm{~cm}$ $(\mathrm{p}<0.01)$ following treatment with prednisolone (data not shown).

A comparison between the two treatments on the overall clinical status of the patients showed that there was no significant difference between the two groups after three months of treatment. Follow up at one year showed that, as a group, they did not differ in the number of disease exacerbations or need for surgical interventions.

\section{Discussion}

Disease states can adversely affect body composition and energy expenditure. Resting energy expenditure decreases following prolonged starvation in the absence of any organic disease. $^{21}$ This is a biological response to conserve energy. It has previously been shown that, in malnourished patients with anorexia nervosa, the REE per unit of lean tissue is reduced. ${ }^{22}$ Our study confirms this finding. We regard anorexia nervosa as a model for prolonged (semi) starvation ${ }^{22}$ without any associated organic disease. Certainly our earlier results $^{22}$ are consistent with those in subjects undergoing prolonged starvation on a voluntary basis. ${ }^{21}$ We therefore chose to compare two groups of malnourished patients-anorexia nervosa, in which there is voluntary food restriction, and Crohn's disease, an inflammatory process with weight loss. The patients with Crohn's disease were also moderately malnourished at the time of exacerbation. In body compartments, lean body mass was significantly depleted. As a proportion of body weight, the ECW compartment was expanded. There was also a significant expansion of ECW relative to ICW. This type of response is compatible with the pattern seen in protein-energy malnutrition in the patients with anorexia nervosa. The patients with Crohn's disease had an ICW that was comparable to that in those with anorexia nervosa (table 1). We have shown in children and adolescents that REE is most closely related to body cell mass measured by ICW, rather than lean body mass or body weight. ${ }^{23}$ However, in Crohn's disease the REE was not reduced (table 1). Thus the patients failed to down regulate their REE in response to weight loss. This may contribute to the ongoing malnutrition along with decreased food intake hitherto believed to be the major cause of weight loss in Crohn's disease. ${ }^{24}$

The reasons for lack of REE adaptation in malnourished patients with Crohn's disease are not known. We suspect that cytokines might have a role in this phenomenon. Increased cytokine production has been observed in patients with active inflammatory bowel disease. ${ }^{25-30}$ Many of the cytokines are known to have adverse effects on nutritional status. These include interleukin 1 (IL-1), tumour necrosis factor (TNF) and interleukin 6 (IL-6). ${ }^{31}$ The cytokines, most notably TNF, are known to produce anorexia, ${ }^{31-33}$ thereby contributing to malnutrition. There are some animal data to suggest that it can also alter energy expenditure. Hoshino et $a l^{34}$ have studied the effects of a 10 day continuous infusion of cachectin (TNF) in rats. Controls and pair-fed rats were used for comparison. Cachectin induced anorexia and weight loss. However, the cachectin-infused rats failed to decrease their REE in response to their weight loss. When compared with the similarly malnourished pair-fed rats the cachectin-infused group was $50 \%$ hypermetabolic. The exact mechanisms involved in this lack of energy down regulation are yet to be defined. We speculate that the increased circulating cytokines lead to a chronically increased secretion of the thermogenic hormones (thyroid and catecholamines) which leads to a relatively hypermetabolic state as is seen in malnourished children with Crohn's disease. An additional observation made by Hoshino et al in their rat study ${ }^{34}$ was that visceral tissues were spared while skeletal muscle was severely wasted. Shetty ${ }^{35}$ has reviewed the literature and has pointed out that differential loss of muscle versus visceral organs may have a differential effect on REE since visceral organs are more metabolically active than skeletal muscle. Thus, the relatively higher ratio of REE to lean body mass in patients with Crohn's disease compared with those with anorexia nervosa may be due to differential losses in muscle versus visceral organ tissue. Our measurements show there are no differences in body cell mass as measured by ICW between the two malnourished groups. But, this does not exclude the possibility of a relative preservation of visceral organ body cell mass in the patients with Crohn's disease.

A potential limitation of the patients with anorexia nervosa as a malnutrition comparison group is that they are older and all female. However, in our larger study of the effects of disease on body composition and REE we found no differences in REE as a result of age or sex when the REE was expressed per unit of lean body mass or ICW. ${ }^{23}$ Following treatment with both enteral nutrition and prednisolone more than $90 \%$ of the patients achieved remission in three months. Both treatments exhibited the same success rate and both treatments restored body weight by increasing both lean tissue and fat tissue. Intracellular water was significantly increased in the enteral nutrition treated group, although the increase in fat was not different between the two groups. The changes in REE were significantly different between groups, and the patients treated with enteral nutrition required a larger number of calories than the prednisolone group as shown by the same weight gain but increased energy expenditure in the enteral nutrition group. This is in accordance with other investigators who showed that, during refeeding, there was an increase in REE. ${ }^{3637}$ 
Another finding from this investigation relates to changes in height. In a short period (three months) a significant increase in height was observed in the enteral nutrition group compared with the prednisolone group in a group of matched male patients. This confirms earlier observations of the beneficial effect of enteral nutrition on linear growth. ${ }^{1}$

In conclusion, children with active Crohn's disease fail to adapt their REE in response to weight loss. This might be a factor contributing to the malnutrition seen in these patients.

We thank Connie Williams $\mathrm{RN}$ for her technical assistance and Claire Smith RN for her care with the children and nursing expertise. M Azcue was supported by a Fellowship from the Terry Fox Programme for Physicians and Scientists and by CNPq-Brazil. M Rashid is supported by a Fellowship from the CNPq-Brazil. M Rashid is supported by a Fellowship from the
Hospital for Sick Children Foundation and Janssen Pharmaceutica.

1 Motil KJ, Grand RJ, Maletskos CJ, Young VR. The effect of disease, drug and diet on whole body protein metabolism in disease, drug and diet on whole body protein metabolism in Pediatr 1982; 101: 345-51.

2 Beeken WL, Busch HJ, Sylvester DL. Intestinal protein loss in Crohn's disease. Gastroenterology 1972; 52: 207-16.

3 Seidman E. Nutritional management of inflammatory bowe disease. Gastroenterol Clin North Am 1989; 18: 129-55.

4 Seidman E, LeLeiko N, Ament A, Berman W, Caplan D, Evans J, et al. Nutritional issues in pediatric inflammatory bowel disease. $\mathcal{F}$ Pediatr Gastroenterol Nutr 1991; 12: 424-38.

5 Belli DC, Seidman E, Bouthillier L, Weber AM, Roy CC, Plentincx M, et al. Chronic intermittent elemental diet improves growth failure in children with Crohn's disease. Gastroenterology 1988; 94: 603-10.

6 Aiges H, Harkowitz J, Rosa J, Daum F. Home nocturnal supplemental nasogastric feedings in growth retarded adolescents with Crohn's disease. Gastroenterology 1989; 97: 905-10.

7 O'Morain C, Segal AM, Levi AJ, Valman HB. Elemental diet in acute Crohn's disease. Arch Dis Child 1983; 53: 44-7.

8 Chan ATH, Fleming CR, O'Fallon WM, Huizenga KA. Estimated versus measured basal energy requirements in patients with Crohn's disease. Gastroenterology 1986; 91 $75-8$.

9 Barot LR, Rombeau JL, Feurer ID, Mullen JL. Caloric requirements in patients with inflammatory bowel disease. Ann Surg 1982; 195: 214-8.

10 Kushner RF, Schoeller DA. Resting and total energy expenditure in patients with inflammatory bowel disease. Am F Clin Nutr 1991; 53: 161-5.

11 Seidman EG, Griffiths AM, Jones A, Issenman R. Semielemental diet versus prednisone in the treatment of active Crohn's disease in children and adolescents [abstract]. Gastroenterology 1993; 104: A778.

12 Moore DJ, Durie PR, Forstner GG, Pencharz PB. The assessment of nutritional status in children. Nutr Res 1985 5: 797-9.

13 Tanner JM, Whitehouse RH, Takaishi M. Standards from birth to maturity for height, weight, height velocity and weight velocity: British children, 1965 .

14 Durnin JVGA, Rahaman MM. The assessment of the amount of fat in the human body from measurements of skin fold thickness. Br $\mathcal{F}$ Nutr 1967; 21: 681-9.

15 Pencharz PB, Azcue MA. Use of bioelectrical impedance analysis (BIA) measurements in the clinical management of malnutrition. Am f Clin Nutr 1996; 64: S485-8.
16 Flynn MA, Woodruf C, Clark J, Chase G. Total body potassium in normal children. Pediatr Res 1972; 6: 239-45.

17 Schoeller DA, van Santen E, Peterson DW, Dietz W, Jaspen $\mathrm{J}$, Klein PD. Total body water measurements in humans with ${ }^{18} \mathrm{O}$ and ${ }^{2} \mathrm{H}$ labelled water. Am F Clin Nutr 1980; 33: 2686-93.

18 Vaisman N, Pencharz PB, Koren G, Johnson JK. Comparison of oral and intravenous administration of sodium bromide for extracellular water measurement. Am f Clin Nutr 1987; 46: $1-4$.

19 Grunow JE, Azcue MP, Berral G, Pencharz PB. Energy expenditure in cystic fibrosis during activities of daily living. F Pediatr 1993; 122: 243-6.

20 World Health Organization. Energy and protein consultation. Technical report series 724 . Geneva: WHO, 1985.

21 Grande F, Anderson JT, Keys A. Changes of basal metabolic rate in man in semi-starvation and refeeding. $\mathcal{F}$ Appl Physiol 1958; 12: 230-8

22 Vaisman N, Rossi MF, Goldberg E, Dibden LJ, Wykes LJ, Pencharz PB. Energy expenditure and body composition in patients with anorexia nervosa. I Pediatr 1988; 113: 919-24

23 Azcue MA. Resting energy expenditure and body composition in normal and sick children. University of Toronto, $\mathrm{PhD}$ thesis, August 1992.

24 Rigaud D, Angel LA, Cerf M, Carduner MJ, Melchior JC, Sautier C, et al. Mechanisms of decreased food intake during weight loss in adult Crohn's disease patients without obvious malabsorption. Am f Clin Nutr 1994; 60: 775-81.

25 Mahida YR, Wu K, Jewel DP. Enhanced production of interleukin $1 \beta$ by mononuclear cells isolated from mucosa with active ulcerative colitis or Crohn's disease. Gut 1989; 30: $835-8$.

26 Niederau C, Backmerhoff F, Schumacher B. Cytokine pattern in serum of patients with active Crohn's disease [abstract]. Gastroenterology 1994; 106: A743.

27 Ligumsky M, Simon PL, Karmeli F, Rachmilewitz D. Role of interleukin-1 in inflammatory bowel disease: enhanced production during active disease. Gut 1990; 31: 686-9.

28 Suzuki Y, Saito H, Kasanuki J, Kishimoto T, Tamura Y, Yoshida S. Significant increase of interleukin-6 production in blood mononuclear leukocytes obtained from patients with active inflammatory bowel disease. Life Sci 1990; 47: 2193-7.

29 Mahida YR, Kurlac L, Gallagher A, Hawkey CJ. High circulating concentrations of interleukin-6 in active Crohn's disease but not ulcerative colitis. Gut 1991; 32: $1531-4$

30 Isaacs KL, Sartor RB, Haskill S. Cytokine messenger RNA profiles in inflammatory bowel disease mucosa detected by polymerase chain reaction amplification. Gastroenterology 1992; 103: 1587-95

31 Grimble RF. Nutrition and cytokine action. Nutr Res Rev 1990; 3: 193-210.

32 Beutler B. Cachexia: a fundamental mechanism. Nutr Rev 1988; 46: 369-73.

33 Stroeber W, James SP. The interleukins. Pediatr Res 1988; 24: $549-57$.

34 Hoshino E, Pichard C, Greenwood CE, Kuo GC, Cameron $\mathrm{RG}$, Kurian R, et al. Body composition and metabolic rate in rat during a continuous infusion of cachectin. $A m \mathcal{F}$ Physiol 1991; 260: E27-36.

35 Shetty PS. Chronic undernutrition and metabolic adaptation. Proc Nutr Soc 1993; 52: 267-84.

36 Heymsfield SB, Casper BS. Continuous nasoenteric feeding: bioenergetics and metabolic response during recovery from semi-starvation. Am f Clin Nutr 1988; 47: 900-10.

37 Vaisman N, Clarke R, Rossi M, Goldberg E, Zello G, Pencharz PB. Protein turnover and resting energy expenditure in patients with undernutrition and chronic lung disease. Am f Clin Nutr 1992; 55: 63-9. 